\title{
ANALISIS TINGKAT KESEHATAN BANK DENGAN MENGGUNAKAN METODE RISK-BASED BANK RATING (RBBR) (STUDI PADA BANK YANG TERDAFTAR DI BANK INDONESIA DALAM LAPORAN TRIWULANAN PERBANKAN TAHUN 2015)
}

\author{
Bayu Rezaldi \\ Bayu.feuad@gmail.com \\ Universitas Ahmad Dahlan \\ Aftoni Sutanto \\ aftoni@yahoo.com \\ Universitas Ahmad Dahlan
}

\begin{abstract}
ABSTRAK
The research objective is to understand bank's health rate that are listed in Bank Indonesia in banking sub-sector period 2015. Bank's health rate is assessed through Risk-Based Bank Rating method which includes four factors such as risk profile, Good Corporate Governance, earning and capital of each bank. This research only considers three factors of four total factors Risk Profile is proxied by Loan to Deposit Ratio(LDR), Earning is proxied by Return On Asset (ROA) to Net Interest Margin (NIM), Capital is proxied by Capital Adequacy Ratio (CAR). The assessment of bank's health rate based on Risk Profile with Loan to Deposit Ratio analysis has shown that some bank area not heahlty with Loan to Deposit Ratio below 85\%, the assessment based on earning with Return On Asset analysis has shown that some banks are not healthy with Return On Asset below $1.25 \%$. The assessment with Net Interest Margin has shown that some bank are not healthy with Net Interest Margin below 2\%. The assessment based on capital by Capital Adequacy Ratio shows positive result for each bank. In general, each bank has Capital Adequacy Ratio aboved $10 \%$. Considering these results, each bank in healthy category.
\end{abstract}

Keyword: Bank’s Health Rate; Risk-Based Bank Rating

\section{PENDAHULUAN}

Bank merupakan suatu industri yang bergerak di bidang keuangan serta memiliki peran dalam perekonomian suatu negara. "Bank adalah lembaga yang memiliki peran dasar sebagai "intermerdiaris" antara pemilik dana (surplus spending unit) dan peminjam dana (defisist spending unit), sehingga bank memiliki produk dasar dan utama bank berupa simpanan dan pinjaman" (Widyaningrum, et.al. 2014). Untuk kelancaran operasional bank, bank memerlukan dana operasional yang dapat memenuhi kebutuhan nasabah. Hal itu merupakan salah satu factor penentu kepercayaan nasabah / masyarakat.

Terwujudnya kepercayaan masyarakat terhadap bank atau lembaga perbankan hal itu mengharuskan lembaga perbankan untuk lebih transparan terhadap masyarakat. Hal itu ditunjukan dari segi laporan keuangan maupun keadaan kesehatan bank. Namun kepercayaan masyarakat sempat hilang terhadap lemabaga perbankan. Peristiwa itu terjadi ketika krisis ekonomi pada pertengah tahun 1997 pada saat bank mengalami kesulitan likuiditas akibat melemahnya nilai tukar rupiah terhadap dollar AS. Krisis tersebut menyebabkan 
pencabutan usaha enam belas bank swasta dan pengambil alihan kepengurusan bank karena besarnya BLBI sudah melebihi $200 \%$ oleh Menteri Keuangan (fadhila, et.al. 2015). Akibat melemahnya nilai tukar rupiah terhadap dollar AS yang terjadi pada pertengahan tahun 1997 tersebut membuat lembaga perbankan Indonesia mengalami kesulitan dalam memnuhi kewajibannya sebagai lembaga perbankan dan tingkat kesehatan perbankan mengalami gangguan. Akibat dampak tersebut masyarak untuk menyimpan uang di bank menjadi menurun. Krisis ekonomi dunia yang terjadi tahun 2015 juga memberikan dampak yang cukup signifikan terhadap perbankan.

Dalam menyikapi krisis moniter yang terjadi pemerintahan melalui Bank Indonesia mengeluarkan peratuaran untuk menilai kebijakan tingkat kesehatan bank. Bank Indonesia, sebagai bentuk perhatian terhadap kesehatan bank telah mengeluarkan kebijakan penilaian tingkat kesehatan bank dengan metode CAMELS berdasarkan PBI No. 6/10/2004 tentang Penilaian Tingkat Kesehatan Bank Umum dengan metode CAMELS yang merupakan penilaian kesehatan bank terhadap 6 faktor yakni Capital, Asset, Management, Earning, Liqudity dan Sensitivity to Market Risk (Widyaningrum, et.al. 2014).

Untuk meningkatkan kualitas penilaian tingkat kesehatan bank, bank Indonesia kembali mengeluarkan peraturan baru untuk menilai tingkat kesehatan bank. Bank Indonesia pada tanggal 25 Oktober 2011 dengan mengeluarkan Peraturan Bank Indonesia No.13/24/PBI/2011. Peraturan baru ini merupakan penyempurnaan dari metode CAMELS yang sebelumnya digunakan. Metode baru yang ditetapkan oleh Bank Indonesia merupakan metode dengan pendekatan risiko yakni Risk-based Bank Rating.Metode Risk-based Bank Rating atau RBBR merupakan metode yang terdiri dari empat faktor penilaian yakni Risk Profile, Good Corporate Governance
(GCG), Earning, dan Capital (Widyaningrum, et.al. 2014).

$$
\text { Loan to Deposit Ratio (LDR) }
$$
merupakan perbandingan antara jumlah kredit yang diberikan terhadap dana pihak ketiga. Besarnya rasio LDR menggambarkan bahwa tanggung jawab bank untuk menyalurkan dananya terpenuhi. Namun belum menggambarkan kelancaran nasabah dalam mengembalikan dananya terhadap bank. Apabila kredit yang diterima terhadap bank itu lancer maka tingkat kesehatan bank itu baik, namun apabila kredit yang diterima terhadap bank itu kurang lancer atau bahkan macet maka tingkat kesehatan bank itu buruk. Loan to Deposit Ratio (LDR) menunjukkan salah satu rasio yang digunakan untuk menghitung risiko liquiditas yang terdapat pada profil risiko. Semakin tinggi LDR maka semakin baik pengelolaan bank dalam membayar hutang-hutangnya. LDR adalah rasio antara seluruh jumlah kredit yang diberikan terhadap dana pihak ketiga. Besarnya jumlah kredit yang disalurkan akan menentukan keuntungan bank. jika bank tidak mampu menyalurkan kredit sementara dana yang terhimpun banyak maka akan menyebabkan bank tersebut rugi (Krisnawati. 2014)

Net Interest Margin (NIM) merupakan rasio yang digunakan oleh manajer bank untuk mengukur aktiva produktif dalam menghasilkan laba perusahaan. NIM merupakan perbandingan antara pendapatan bunga bersih terhadap total asset produktif. Besar rasio NIM dapat menunjukan kemampuan bank dalam memenuhi kelangsungan hidup operasional bank. Semakin besar rasio NIM maka semakin bagus kelangsungan operasional bank, begitu pula semakin kecil rasio NIM maka kelangsungan operasional bank kurang bagus. Rasio NIM memili pengaruh terhadap tingkat kesehatan bank. Net Interest Margin (NIM) menggambarkan tingkat jumlah pendapatan bunga bersih yang diperoleh dengan menggunakan 
aktiva produktif yang dimiliki oleh bank, jadi semakin besar nilai NIM maka akan semakin besar pula keuntungan yang diperoleh dari pendapatan bunga dan akan berpengaruh pada tingkat kesehatan bank (Permatasari, 2015).

Return On Assets (ROA) merupakan rasio yang digunakan untuk mengukur kemampuan manajemen bank dalam memperoleh profitabilitas dan mengelola tingkat efesiensi usaha bank secara keseluruhan. Semakin besar nilai rasio ini menunjukkan tingkat rentabilitas usaha bank semakin baik atau sehat. Semakin tinggi nilai ROA, semakin efektif pula pengelolaan aktiva perusahaan dan semakin kecil prediksi bank mengalami kondisi yang bermasalah (Permatasari, 2015). Sehingga suatu lembaga perbankan dalam mengukur efisiensi usaha secara keseluruhan dalam kemampuan manajemen bank menggunakan rasio ROA.

\section{Capital Adequacy Ratio (CAR)}

yaitu kewajiban penyediaan modal minimum yang arus selalu dipertahankan oleh setiap bank sebagai suatu proporsi tertentu dari total Aktiva Tertimbang Menurut Risiko (ATMR). (Capital Adequacy Ratio) adalah kecukupan modal yang menunjukkan kemampuan bank dalam mempertahankan modal yang mencukupi dan kemampuan manajemen bank dalam mengidentifikasi, mengukur, mengawasi, dan mengontrol risiko-risiko yang dapat berpengaruh terhadap besarnya modal bank (Hakim, 2014). Kecukupan modal dapat menggambar kemampuan suatu bank untuk mempertahankan modal yang mencukupi dalam menutupi modal aset yang berisiko. Semakin besar CAR maka semakin bagus kecukupan modal bank untuk menutupi aset-aset yang berisiko, begitu pula semakin kecil CAR maka kemampuan menutupi assetaset yang berisiko semakin rendah.

\section{Rumusan Masalah}

1. Bagaimana tingkat kesehatan bank yang terdaftar di BI dengan rasio LDR menggunakan metode RBBR?

2. Bagaimana tingkat kesehatan bank yang terdaftar di BI dengan rasio NIM menggunakan metode RBBR?

3. Bagaimana tingkat kesehatan bank yang terdaftar di BI dengan rasio ROA menggunakan metode RBBR?

4. Bagaimana tingkat kesehatan bank yang terdaftar di BI dengan rasio CAR menggunakan metode RBBR?

\section{REVIEW LITERATUR DAN HIPOTESIS}

\section{Landasan Teori \\ Pengertian Bank}

Bank merupakan lembaga keuangan yang menghimpun dana masyarakat dalam bentuk simpanan dan menyalurkan dalam bentuk kredit kepada masyarakat, yang membutuhkan dana. Bank sangat dibutuhkan oleh masyarakat baik masyarakat yang memiliki uang maupun masyarakat yang memerlukan uang untuk memenuhi kebutuhannya. Bank sangat berperan dalam meningkatkan perekonomian suatu Negara, maupun masyarakat luas (Ismail, 2010).

Bank bukanlah suatu hal yang asing bagi masyarkat di Negara maju. Masyarakat di Negara maju sangat membutuhkan keberadaan bank. Bank dianggap sebagai suatu lembaga keuangan yang aman dalam melakukan berbagai macam aktivitas keuangan. Aktifitas keuangan yang sering dilakukan masyarakat di Negara maju antara lain aktivitas penyimpanan dana, investasi, pengiriman uang dari suatu tempat ke tempat lain atau dari suatu daerah ke daerah lain dengan cepat dan aman, serta aktivitas keuangan lainnya. Bank juga merupakan salah satu lembaga yang sangat penting dalam mendorong pertumbuhan perekonomian suatu Negara, bahkan pertumbuhan bank di suatu Negara dipakai 
sebagai ukuran pertumbuhanperekonomian Negara tersebut (Ismail, 2010).

\section{Modal Bank}

Modal bank dipergunakan untuk menentukan PDN terdiri dari modal inti (tier 1) modal pelengkap (tier 2). Modal inti terdiri dari modal disetor dan tambahannya, agio saham, cadangan umum, cadangan khusus, laba ditahan, laba tahun lalu, laba tahun berjalan (50\%), rugi tahun berjalan (mengurangi). Sedangkan modal pelengkap terdiri dari rebaluasi aktiva tetap, cadangan penyisihan aktiva produktif hanya dari cadangan umum maksimum $1,25 \%$ dari aktiva tertimbang menurut risiko (ATMR), pinjaman modal, pinjaman subordinasi (maksimum 50\% dari modal inti). Besarnya modal pelengkap yang diperhitungkan dalam posisi devisa neto maksimum sebesar modal inti (Taswan, 2010).

\section{Metode Risk Based Bank Rating}

Profil Risiko (Risk Profile)

Berdasarkan PBI No.

13/1/PBI/2011 bank melakukan penilaian terhadap risiko inheren dan kualitas penerapan manajemen risiko dalam kegiatan operasional terhadap delapan risiko, yakni risiko kredit, risiko pasar, risiko likuiditas, risiko operasional, risiko hukum, risiko stratejik, risiko kepatuhan, dan risiko reputasi. Penelitian ini mengukur satu risiko pada faktor risk profile menggunakan rasio Loan to Deposit Ratio (LDR) untuk mengukur risiko likuiditas.

LDR $=\frac{\text { Total Kredit }}{\text { Dana Pihak Ketiga }} \mathrm{X} 100 \%$
\begin{tabular}{|l|l|l|}
\hline No & \multicolumn{1}{|c|}{ Rasio } & \multicolumn{1}{c|}{ Predikat } \\
\hline 1 & $50 \%<$ LDR $\leq 75 \%$ & Sangat Baik \\
\hline 2 & $75 \%<$ LDR $\leq 85 \%$ & Baik \\
\hline 3 & $85 \%<$ LDR $\leq 100 \%$ & Cukup Baik \\
\hline 4 & $100 \%<$ LDR $\leq 120 \%$ & Kurang Baik \\
\hline 5 & LDR $>120 \%$ & Tidak Baik \\
\hline
\end{tabular}

\section{Good Corporate Governance (GCG)}

Penilaian pelaksanaan GCG bank mempertimbangkan faktor - faktor penilaian GCG secara komprehensif dan terstruktur, mencakup governance structur, governance process, dan governance outcome. Berdasarkan SE BI No. 15/15/DPNP Tahun 2013 Bank diharuskan melakukan penilaian sendiri (self assessment) secara berkala meliputi sebelas aspek penilaian pelaksanaan GCG.

\section{Rentabilitas (earning)}

Return On Asset

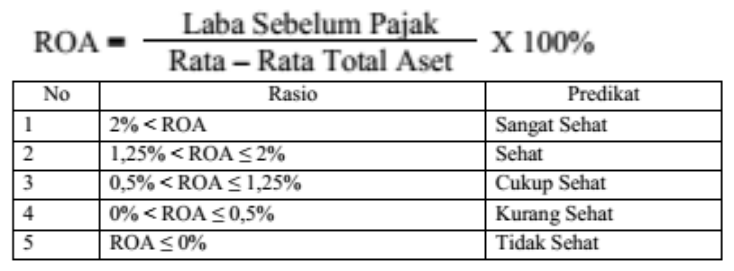

Net Interest Margin

NIM $=\frac{\text { Pendapatan Bunga Bersih }}{\text { Rata }- \text { Rata Total Earning Aset }}$ X $100 \%$
\begin{tabular}{|l|l|l|}
\hline No & \multicolumn{1}{|c|}{ Rasio } & \multicolumn{1}{c|}{ Predikat } \\
\hline 1 & $3 \%<$ NIM & Sangat Sehat \\
\hline 2 & $2 \%<$ NIM $\leq 3 \%$ & Sehat \\
\hline 3 & $1,5 \%<$ NIM $\leq 2 \%$ & Cukup Sehat \\
\hline 4 & $1 \%<$ NIM $\leq 1,5 \%$ & Kurang Sehat \\
\hline 5 & NIM $\leq 1 \%$ & Tidak Sehat \\
\hline
\end{tabular}

\section{Permodalan (Capital)}

Rasio Capital Adequacy Ratio (CAR) dapat digunakan untuk mengukur kecukupan modal yang dimiliki bank dan pemenuhan Kewajiban Penyediaan Modal Minimum (KPMM). Rumus CAR yang digunakan adalah:

CAR= \begin{tabular}{c|c|} 
Aktiva Tertimbang Menurut Risiko \\
\cline { 2 - 3 }
\end{tabular}
\begin{tabular}{|l|l|l|}
\hline No & \multicolumn{1}{|c|}{ Rasio $100 \%$} \\
\hline 1 & $12 \%<$ CAR & Predikat \\
\hline 2 & $9 \%<$ CAR $\leq 12 \%$ & Sangat Sehat \\
\hline 3 & $8 \%<$ CAR $\leq 9 \%$ & Cukup Sehat \\
\hline 4 & $6 \%<$ CAR $\leq 8 \%$ & Kurang Sehat \\
\hline 5 & CAR $\leq 6 \%$ & Tidak Sehat \\
\hline
\end{tabular}




\section{Penelitian Terdahulu}

\begin{tabular}{|c|c|c|c|}
\hline No & Peneliti & Judul & Hasil \\
\hline 1 & $\begin{array}{l}\text { Permatasari et.al., } \\
2015\end{array}$ & 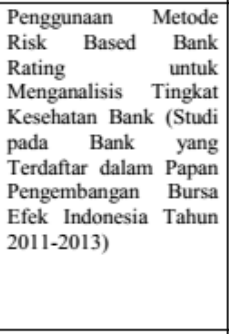 & $\begin{array}{lr}\text { Rasio NPL, } & \text { LDR, } \\
\text { ROA, NIM, dan CAR } \\
\text { serta publikasi hasil selff' } \\
\text { assessment } & \text { GCG } \\
\text { menunjukkan } & \text { bahwa } \\
\text { tidak ada rampel } & \text { sampel } \\
\text { peneliti } & \text { yang } \\
\text { menghasilkan predikat } & \text { sehat secara berturut- } \\
\text { turut atas semua rasio } \\
\text { yang digunakan dalam } \\
\text { selama periode } & 2011- \\
2013 & \\
\end{array}$ \\
\hline \multirow[t]{2}{*}{2} & $\begin{array}{l}\text { Fadhila et.al., } \\
2015\end{array}$ & $\begin{array}{lr}\text { Analisis } & \text { Tingkat } \\
\text { Kesehatan } & \text { Bank } \\
\text { Dengan Menggunakan } \\
\text { Metode Risk Based } \\
\text { Bank Rating (RBBR) } \\
\text { studi pada Bank Milik } \\
\text { Pemerintah Pusat Yang } \\
\text { Terdaftar di Bursa Efek } \\
\text { Indonesia Tahun 2011- } \\
2013 \text { ) } \\
\end{array}$ & $\begin{array}{l}\text { Penilaian faktor Risk } \\
\text { Profile menunjukkan } \\
\text { rata-rata NPL empat } \\
\text { bank milik pemerintah } \\
\text { pusat di bawah } 5 \% \\
\text { dengan rata-rata IRR } \\
107,01 \% \text {. Rasio LDR } \\
\text { bank milik pemerintah } \\
\text { pusat rata-rata sebesar } \\
112,97 \% \text {. Tinggi rasio } \\
\end{array}$ \\
\hline & & & \begin{tabular}{|lrr} 
LDR disebabkan & \multicolumn{2}{r}{ karena tingginya dana } \\
pihak ketiga yang \\
dialokasikan r pada \\
kredit yang diberikan \\
bank. \\
\end{tabular} \\
\hline 3 & $\begin{array}{l}\text { Widyaningrum } \\
\text { et.al., } 2014\end{array}$ & $\begin{array}{l}\text { Analisis Tingkat } \\
\text { Kesehatan Bank dengan } \\
\text { Menggunakan Metode } \\
\text { Risk Based Bank Rating } \\
\text { (RBBR) studi pada } \\
\text { bank yang terdaftar di } \\
\text { Bursa Efek Indonesia } \\
\text { dalam IHSG Sub Sektor } \\
\text { Perbankan Tahun 2012 }\end{array}$ & $\begin{array}{l}\text { Rasio Return on Asset } \\
\text { (ROA) } \\
\text { dikategorikan kedalam } \\
\text { bank yang sehat, } \\
\text { kecuali } 5 \text { bank, rasio } \\
\text { Net Interest Margin } \\
\text { (NIM) menunjukkan } \\
\text { seluruh bank yang } \\
\text { menjadi sampel dalam } \\
\text { kategori sehat, rasio } \\
\text { Capital Adequacy } \\
\text { Ratio (CAR) setiap } \\
\text { bang masuk dalam } \\
\text { kategori sehat. }\end{array}$ \\
\hline 4 & Septyaning, 2014 & $\begin{array}{lr}\text { Analisa } & \text { Kinerja Bank } \\
\text { Dengan } & \text { Penerapan } \\
\text { Metode Risk Based } \\
\text { Bank Rating (studi pada } \\
\text { perbankan swasta yang } \\
\text { listing di BEI) }\end{array}$ & 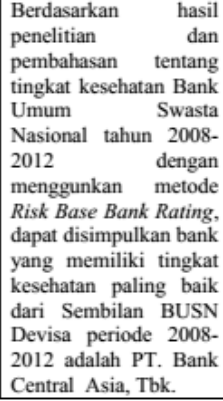 \\
\hline
\end{tabular}

\section{METODE PENELITIAN}

\section{Populasi dan Sampel}

Populasi yang digunakan dalam penelitian ini adalah Bank Umum Konvensional yang terdaftar di Bank Indonesia pada tahun 2015. Dari populasi Bank Umum Konvensional, populasi yang diambil menggunakan purposive sampling. Pemilihan sampel dailakukan secara purposive sampling, yaitu populasi yang akan dijadikan sampel penelitian adalah yang memenuhi kriteria sampel tertentu sesuai dengan yang dikehendaki peneliti. Proses seleksi sampel didasarkan oleh kriteria yang ditetapkan. Adapun kriteria yang digunakan dalam menentukan sampel yaitu, Bank Umum Konvensional yang menerbitkan laporan keuangan triwulanan secara lengkap pada tahun 2015.

\section{Analisis Data}

Berikut adalah langkah - langkah analisis data yang digunakan oleh peneliti :

1. Melakukan perhitungan dan analisis Risk Profile, rasio likuiditas diukur dengan ratio Loan to Deposit Ratio (LDR).

2. Melakukan perhitungan dan analisis Earning, meliputi rasio Net Interest Margin (NIM), Return On Assets (ROA).

3. Melakukan perhitungan dan analisis Capital. Meliuti rasio Capital Adequacy Ratio (ROA)

\section{HASIL PENELITIAN DAN PEMBAHASAN}

\section{Hasil dan Pembahasan}

\section{A. Profil Risiko (Risk Profile)}

Risk Profile atau profil risiko merupakan penilaian terhadap risiko inheren dan kualitas penerapan manajemen risiko dalam operasional bank sebagai strategi bisnis bank. Berdasarkan lampiran Surat Edaran Bank Indonesia No. 13/24/DPNP 25 Oktober 2011, Bank Indonesia mengklarifikasikan risiko ke dalam 8 jenis risiko yaitu risiko kredit, risiko pasar, risiko likuiditas, risiko operasional, risiko hukum, risiko stratejik, risiko kepatuhan, dan risiko reputasi. Risiko tersebut mengarah pada prinsip-prinsip umum penilaian tingkat kesehatan bank umum (Krisnawati. 2014)

Tabel 4.1 dapat diketahui bahwa hampir dari keseluruhan bank mendapatkan predikat baik dinilai dengat aspek LDR. Bank yang 
mendapatkan predikat dibawah baik terdiri dari 4 bank, yakni bank yang memiliki nilai LDR lebih dari $85 \%$, yakni Bank Negara Indonesia pada laporan triwulan 1 sebesar $87,76 \%$, laporan triwulan 2 sebesar $87,63 \%$, dan laporan triwulan 3 sebesar $87,67 \%$, Bank of India Indonesia pada laporan triwulan 1 sebesar 85,21\%, Bank QNB pada laporan triwulan 1 sebesar $96,33 \%$, laporan triwulan 2 sebesar $97,25 \%$, dan laporan triwulan ke 3 sebesar 104,64\%, Bank Rakyat Indonesia pada laporan triwulan 2 sebesar $87,87 \%$. Ldr yang semakin meningkat menunjukkan semakin rendahnya likuiditas bank karena jumlah dana masyarakat yang disalurkan ke kredit terlalu besar.

1. Loan To Deposit Ratio (LDR)

\begin{tabular}{|c|c|c|c|c|}
\hline No & NAMA BANK & PERIODE & LDR & PREDIKAT \\
\hline \multirow{3}{*}{1} & \multirow{3}{*}{ Bank Capital Indonesia } & Triwulan I & $58,31 \%$ & Sangat Baik \\
\hline & & Triwulan II & $61,16 \%$ & Sangat Baik \\
\hline & & Triwulan III & $58.73 \%$ & Sangat Baik \\
\hline \multirow[t]{3}{*}{2} & \multirow{3}{*}{ Bank Central Asia } & Triwulan I & $74,91 \%$ & Sangat Baik \\
\hline & & Triwulan II & $75,69 \%$ & Baik \\
\hline & & Triwulan III & $78,10 \%$ & Baik \\
\hline \multirow[t]{3}{*}{3} & \multirow{3}{*}{ Bank Mandiri } & Triwulan I & $83,80 \%$ & Baik \\
\hline & & Triwulan II & $82,97 \%$ & Baik \\
\hline & & Triwulan III & $84,27 \%$ & Baik \\
\hline \multirow[t]{3}{*}{4} & \multirow{3}{*}{ Bank MNC Internasional } & Triwulan I & $73.99 \%$ & Sangat Baik \\
\hline & & Triwulan II & $80,09 \%$ & Baik \\
\hline & & Triwulan III & $80,24 \%$ & Baik \\
\hline \multirow[t]{3}{*}{5} & \multirow{3}{*}{ Bank Mutiara } & Triwulan I & $78,57 \%$ & Baik \\
\hline & & Triwulan II & $77,10 \%$ & Baik \\
\hline & & Triwulan III & $82,35 \%$ & Baik \\
\hline \multirow[t]{3}{*}{6} & \multirow{3}{*}{ Bank Negara Indonesia } & Triwulan I & $87,76 \%$ & Cukup Baik \\
\hline & & Triwulan II & $87,63 \%$ & Cukup Baik \\
\hline & & Triwulan III & $87,67 \%$ & Cukup Baik \\
\hline \multirow[t]{3}{*}{7} & \multirow{3}{*}{ Bank Of India Indonesia } & Triwulan I & $85,21 \%$ & Cukup Baik \\
\hline & & Triwulan II & $75,24 \%$ & Baik \\
\hline & & Triwulan III & $79,10 \%$ & Baik \\
\hline \multirow[t]{3}{*}{8} & \multirow{3}{*}{ Bank QNB } & Triwulan I & $96,33 \%$ & Cukup Baik \\
\hline & & Triwulan II & $97,25 \%$ & Cukup Baik \\
\hline & & Triwulan III & $104,64 \%$ & Kurang Baik \\
\hline \multirow[t]{3}{*}{9} & \multirow{3}{*}{ Bank Rakyat Indonesia } & Triwulan I & $80,47 \%$ & Baik \\
\hline & & Triwulan II & $87,87 \%$ & Cukup Baik \\
\hline & & Triwulan III & $84.89 \%$ & Baik \\
\hline \multirow[t]{3}{*}{10} & \multirow{3}{*}{ Bank Victoria International } & Triwulan I & $63,69 \%$ & Sangat Baik \\
\hline & & Triwulan II & $77,72 \%$ & Baik \\
\hline & & Triwulan III & $77,40 \%$ & Baik \\
\hline
\end{tabular}

Dari tabel 4.1 dapat diketahui bahwa bank yang masuk dalam predikat baik dari variabel LDR adalah a. Bank Capital Indonesia predikat baik dari tiga laporan triwulanan.

b. Bank Central Asia predikat baik dari tiga laporan triwulanan.

c. Bank Mandiri predikat baik dari tiga laporan triwulan.

d. Bank MNC Internasional predikat baik dari tiga laporan triwulanan.

e. Bank Mutiara predikat baik dari tiga laporan triwulanan.

f. Bank Of India Indonesia predikat baik dari dua laporan triwulanan. g. Bank Rakyat Indonesia predikat baik dari dua laporan triwulanan.

h. Bank Victoria International predikat baik dari tiga laporan triwulanan.

\section{B. Rentabilitas (Earning)}

Penilaian faktor rentabilitas mencakupi penilaian terhadap kinerja rentabilitas, sumber-sumber yang terkait pada rentabilitas, sustainability earnings bank, serta manajemen rentabilitas. Penilaian ini dilakukan dengan mempertimbangkan tingkat, trend, struktur, stabilitas rentabilitas bank, dan memperhatikan kinerja peer group,serta manajemen rentabilitas baik melalui analisis aspek kuantitatif maupun kualitatif (Krisnawati. 2014).

\section{Return On Asset (ROA)}

\begin{tabular}{|c|c|c|c|c|}
\hline No & NAMA BANK & PERIODE & ROA & PREDIKAT \\
\hline \multirow[t]{3}{*}{1} & \multirow{3}{*}{ Bank Capital Indonesia } & Triwulan I & $1,33 \%$ & Sehat \\
\hline & & Triwulan II & $1,23 \%$ & Cukup Sehat \\
\hline & & Triwulan III & $1,13 \%$ & Cukup Sehat \\
\hline \multirow[t]{3}{*}{2} & \multirow{3}{*}{ Bank Central Asia } & Triwulan I & $3,48 \%$ & Sangat Sehat \\
\hline & & Triwulan II & $3,75 \%$ & Sangat Sehat \\
\hline & & Triwulan III & $3,86 \%$ & Sangat Sehat \\
\hline \multirow[t]{3}{*}{3} & \multirow{3}{*}{ Bank Mandiri } & Triwulan I & $3,54 \%$ & Sangat Sehat \\
\hline & & Triwulan II & $3,21 \%$ & Sangat Sehat \\
\hline & & Triwulan III & $3,00 \%$ & Sangat Sehat \\
\hline \multirow[t]{3}{*}{4} & \multirow{3}{*}{ Bank MNC Internasional } & Triwulan I & $0,11 \%$ & Kurang Sehat \\
\hline & & Triwulan II & $0,10 \%$ & Kurang Sehat \\
\hline & & Triwulan III & $0,13 \%$ & Kurang Sehat \\
\hline \multirow[t]{3}{*}{5} & \multirow{3}{*}{ Bank Mutiara } & Triwulan I & $(3,09 \%)$ & Tidak Sehat \\
\hline & & Triwulan II & $(3,79 \%)$ & Tidak Sehat \\
\hline & & Triwulan III & $(5,31 \%)$ & Tidak Sehat \\
\hline \multirow[t]{3}{*}{6} & \multirow{3}{*}{ Bank Negara Indonesia } & Triwulan I & $3,55 \%$ & Sangat Sehat \\
\hline & & Triwulan II & $1,48 \%$ & Sehat \\
\hline & & Triwulan III & $2,45 \%$ & Sangat Sehat \\
\hline \multirow[t]{3}{*}{7} & \multirow{3}{*}{ Bank Of India Indonesia } & Triwulan I & $3,91 \%$ & Sangat Sehat \\
\hline & & Triwulan II & $1,95 \%$ & Sehat \\
\hline & & Triwulan III & $0,81 \%$ & Cukup Sehat \\
\hline \multirow[t]{3}{*}{8} & \multirow{3}{*}{ Bank QNB } & Triwulan I & $0,26 \%$ & Kurang Sehat \\
\hline & & Triwulan II & $0,34 \%$ & Kurang Sehat \\
\hline & & Triwulan III & $0,41 \%$ & Kurang Sehat \\
\hline \multirow[t]{3}{*}{9} & \multirow{3}{*}{ Bank Rakyat Indonesia } & Triwulan I & $3,99 \%$ & Sangat Sehat \\
\hline & & Triwulan II & $3,91 \%$ & Sangat Sehat \\
\hline & & Triwulan III & $3,95 \%$ & Sangat Sehat \\
\hline \multirow[t]{3}{*}{10} & \multirow{3}{*}{ Bank Victoria International } & Triwulan I & $0,93 \%$ & Cukup Sehat \\
\hline & & Triwulan II & $0,97 \%$ & Cukup Sehat \\
\hline & & Triwulan III & $0,94 \%$ & \begin{tabular}{|l} 
Cukup Sehat \\
\end{tabular} \\
\hline
\end{tabular}

Berdasarkan tabel 4.2 dapat diketahui bahwa lebih dari hampir keseluruhan bank mendapatkan predikat sehat dinilai dengan aspek ROA.

Bank yang mendapat predikat tidak sehat hanya terdiri dari 6 bank, yakni bank yang memiliki nilai ROA di bawah $1,25 \%$ yaitu, Bank Capital Indonesia pada laporan triwulan 2 sebesar $1,23 \%$ dan laporan triwulan 3 sebesar 1,13\%, Bank MNC 
Internasional pada laporan triwulan 1 sebesar $0,11 \%$, triwulan 2 sebesar $0,10 \%$, dan triwulan 3 sebesar $0,13 \%$, Bank Mutiara pada laporan triwulan 1 sebesar $-3,09 \%$, triwulan 2 sebesar $3,79 \%$, dan triwulan 3 sebesar $-5,31 \%$, Bank Of India Indonesia pada laporan triwulan 3 sebesar 0,81\%, Bank QNB pada laporan triwulan 1 sebesar $0,26 \%$, triwulan 2 sebesar $0,34 \%$, dan triwulan 3 sebesar $0,41 \%$, Bank Victoria International pada laporan triwulan 1 sebesar $0,93 \%$, triwulan 2 sebesar $0,97 \%$, dan triwulan 3 sebesar $0,94 \%$. Semakin kecil nilai ROA berarti menunjukkan bank belum efektif dalam menghasilkan keuntungan sehingga dapat digolongkan dalam kriteria bank yang tidak sehat.

\section{Net Interest Margin (NIM)}

\begin{tabular}{|c|c|c|c|c|}
\hline No & NAMA BANK & \begin{tabular}{|l} 
PERIODE \\
\end{tabular} & NIM & PREDIKAT \\
\hline \multirow[t]{3}{*}{1} & \multirow{3}{*}{ Bank Capital Indonesia } & Triwulan I & $4,44 \%$ & Sangat Sehat \\
\hline & & Triwulan II & $4,47 \%$ & \begin{tabular}{|l} 
Sangat Sehat \\
\end{tabular} \\
\hline & & Triwulan III & $4,62 \%$ & Sangat Sehat \\
\hline \multirow[t]{3}{*}{2} & \multirow{3}{*}{ Bank Central Asia } & \begin{tabular}{|l|} 
Triwulan I \\
\end{tabular} & $6,53 \%$ & Sangat Sehat \\
\hline & & Triwulan II & $6,57 \%$ & \begin{tabular}{|l} 
Sangat Sehat \\
\end{tabular} \\
\hline & & Triwulan III & $6,61 \%$ & Sangat Sehat \\
\hline \multirow[t]{3}{*}{3} & \multirow{3}{*}{ Bank Mandiri } & Triwulan I & $5,41 \%$ & \begin{tabular}{|l} 
Sangat Sehat \\
\end{tabular} \\
\hline & & Triwulan II & $5,58 \%$ & \begin{tabular}{|l} 
Sangat Sehat \\
\end{tabular} \\
\hline & & Triwulan III & $5,63 \%$ & \begin{tabular}{|l} 
Sangat Sehat \\
\end{tabular} \\
\hline \multirow[t]{3}{*}{4} & \multirow{3}{*}{ Bank MNC Internasional } & \begin{tabular}{|l|} 
Triwulan I \\
\end{tabular} & $3,56 \%$ & \begin{tabular}{|l|} 
Sangat Sehat \\
\end{tabular} \\
\hline & & Triwulan II & $3,24 \%$ & \begin{tabular}{|l|} 
Sangat Sehat \\
\end{tabular} \\
\hline & & Triwulan III & $3,27 \%$ & \begin{tabular}{|l} 
Sangat Sehat \\
\end{tabular} \\
\hline \multirow[t]{3}{*}{5} & \multirow{3}{*}{ Bank Mutiara } & Triwulan I & $0,27 \%$ & \begin{tabular}{|l|} 
Tidak Sehat \\
\end{tabular} \\
\hline & & Triwulan II & $0,43 \%$ & \begin{tabular}{|l|} 
Tidak Sehat \\
\end{tabular} \\
\hline & & Triwulan III & $0,71 \%$ & \begin{tabular}{|l|} 
Tidak Sehat \\
\end{tabular} \\
\hline \multirow[t]{3}{*}{6} & \multirow{3}{*}{ Bank Negara Indonesia } & Triwulan I & $6,52 \%$ & Sangat Sehat \\
\hline & & \begin{tabular}{|l} 
Triwulan II \\
\end{tabular} & $6,53 \%$ & \begin{tabular}{|l|} 
Sangat Sehat \\
\end{tabular} \\
\hline & & Triwulan III & $6,50 \%$ & \begin{tabular}{|l} 
Sangat Sehat \\
\end{tabular} \\
\hline \multirow[t]{3}{*}{7} & \multirow{3}{*}{ Bank Of India Indonesia } & Triwulan I & $4,73 \%$ & Sangat Sehat \\
\hline & & Triwulan II & $4,26 \%$ & \begin{tabular}{|l} 
Sangat Sehat \\
\end{tabular} \\
\hline & & \begin{tabular}{|l|} 
Triwulan III \\
\end{tabular} & $3,90 \%$ & \begin{tabular}{|l|} 
Sangat Sehat \\
\end{tabular} \\
\hline \multirow[t]{3}{*}{8} & \multirow{3}{*}{ Bank QNB } & \begin{tabular}{|l|} 
Triwulan I \\
\end{tabular} & $2,33 \%$ & Sehat \\
\hline & & Triwulan II & $2,54 \%$ & Sehat \\
\hline & & Triwulan III & $2,72 \%$ & Sehat \\
\hline \multirow[t]{3}{*}{9} & \multirow{3}{*}{ Bank Rakyat Indonesia } & \begin{tabular}{|l|} 
Triwulan I \\
\end{tabular} & $7,57 \%$ & Sangat Sehat \\
\hline & & \begin{tabular}{|l|} 
Triwulan II \\
\end{tabular} & $7,88 \%$ & Sangat Sehat \\
\hline & & \begin{tabular}{|l} 
Triwulan III \\
\end{tabular} & $8,08 \%$ & \begin{tabular}{|l|} 
Sangat Sehat \\
\end{tabular} \\
\hline \multirow[t]{3}{*}{10} & \multirow{3}{*}{ Bank Victoria International } & \begin{tabular}{|l|} 
Triwulan I \\
\end{tabular} & $1,91 \%$ & Cukup Sehat \\
\hline & & \begin{tabular}{|l} 
Triwulan II \\
\end{tabular} & $2,46 \%$ & \begin{tabular}{|l|} 
Sehat \\
\end{tabular} \\
\hline & & \begin{tabular}{|l} 
Triwulan III \\
\end{tabular} & $2,47 \%$ & Sehat \\
\hline
\end{tabular}

Berdasarkan tabel 4.3 dapat diketahui bahwa NIM yang dimiliki hampir oleh keseluruhan bank mendapatakan predikat sehat. Bank yang tidak sehat hanya 2 bank, yakni bank yang memiliki nilai NIM dibawah 2\% yaitu, Bank Mutiara pada laporan triwulan 1 sebesar $0,27 \%$, triwulan 2 sebesar $0,43 \%$, dan triwulan 3 sebesar $0,71 \%$, Bank Victoria International pada laporan triwulan 1 sebesar 1,91\%. Hasil NIM ini menunjukkan bahwa semakin baik kinerja bank yang dimiliki bank sangat tinggi untuk mengantisipasi potensi kerugian dan meningkatkan modal.

\section{Modal (Capital)}

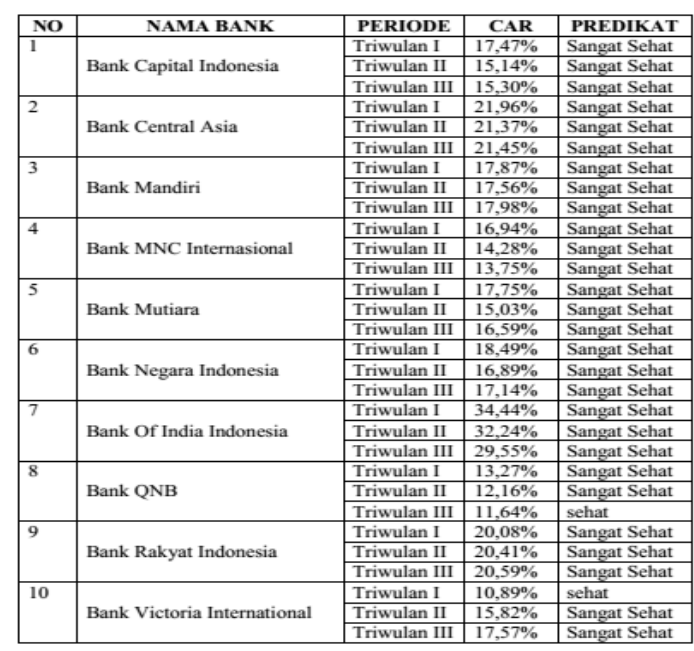

Berdasarkan hasil perhitungan CAR yang ditunjukkan oleh tabel 4.4 dapat diketahui keseluruhan bank yang menjadi sampel menunjukkan hasil yang positif, sehingga keseluruhan bank dapat digolongkan ke dalam predikat bank sehat. CAR keseluruhan bank memiliki nilai yang melebihi rasio minimum CAR sebesar $8 \%$ yang telah ditetapkan oleh Bank Indonesia berdasarkan keputusan direksi BI No 26/20/Kep/DIR dan SE BI No 26/2/BPPP. Nilai CAR yang positif menunjukkan bahwa bank tersebut memiliki modal yang kuat, sehingga mampu untuk mengatasi jika bank mengalami kerugian. Kecukupan modal yang kuat diharapkan agar bank mampu mengatasi kerugian yang terjadi dan melindungi sumber dana yang ada terutama dana yang tidak dijamin oleh pemerintah 


\section{KESIMPULAN DAN SARAN}

\section{Kesimpulan}

1. Penilaian yang dilakukan dalam penelitian ini melibatkan tiga faktor dari metode RBBR yakni Risk Profile, Earning, dan Capital. Hasil yang diperoleh dari ketiga faktor tersebut menunjukkan bahwa setiap bank yang dinilai dengan faktor Risk Profile (Profil Risiko) menggunakan Loan to Deposit Ratio (LDR) dapat dikategorikan ke dalam bank yang baik, kecuali 4 bank yang termasuk dalam kriteria bank yang kurang baik. Penilaian faktor Earning atau Rentabilitas dengan menggunakan rasio Return On Asset (ROA) menunjukkan bahwa hampir sebagian bank yang menjadi sampel masuk kedalam kriteria bank sehat, kecuali 6 bank yang mendapatkan kriteria bank kurang sehat, dan dengan menggunakan rasio Net Interest Margin (NIM) menunjukkan bahwa sebagian besar bank yang menjadi sampel masuk kedalam kriteria sehat, kecuali 2 bank yang mendapatkan kriteria bank kurang sehat. Penilaian untuk faktor Capital (Modal) menggunakan rasio Capital Adequacy Ratio (CAR), hasil penilaiannya menunjukkan bahwa setiap bank masuk kedalam kategori bank sehat.

2. Hasil penelitian tingkat kesehatan bank dengan metodi Risk - Based Bank Rating (RBBR). Penelitian dengat faktor Risk Profile (Profil Risiko) menggunakan rasio Loan to Deposit Ratio (LDR) menunjukkan bank yang sangat baik dengan nilai LDR yang paling baik adalah Bank Capital Indonesia dengan LDR sebesar 58,31\% sedangkan Bank yang masuk ke dalam bank yang kurang baik adalah Bank QNB dengan nilai LDR 104,64\%. Penelitan faktor Earning (Rentabilitas) menggunakan rasio Return On Asset
(ROA) menunjukkan bank yang sehat dengan nilai ROA yang paling baik adalah Bank Rakyat Indonesia dengan ROA sebesar 3,99\% sedangkan bank yang masuk ke dalam bank yang tidak sehat adalah Bank Mutiara dengan nilai ROA $-5,31 \%$. Hasil dari perhitungan rasio Net Interest Margin (NIM) menunjukkan bank masuk ke dalam kategori sehat, dengan nilai NIM secara keseluruhan rata - rata di atas 2\%. Bank yang memiliki nilai NIM yang paling baik adalah Bank Rakyat Indonesia dengan NIM sebesar $8,08 \%$, sedangkan bank dengan nilai NIM yang kecil adalah Bank Mutiara dengan NIM sebesar 0,27\%. Penelitian faktor Capital (Modal) dengan menggunakan rasio Capital Adequacy Ratio (CAR) menunjukkan bahwa keseluruhan bank termasuk ke dalam kriteria bank sehat dengan nilai CAR yang berada di atas $8 \%$. Nilai Car yang paling baik diantara bank - bank yang menjadi sampel diperoleh Bank Of India Indonesia dengan CAR sebesar 34,44\%.

\section{Saran}

1. Setiap bank sebaiknya mengurangi jumlah kredit yang bermasalah, karena dapat dilihat dari rasio Loan to Deposit Ratio (LDR) yang menggambarkan masih lumayan banyak bank yang masuk dalam sampel dalam kategori kurang baik.

2. Setiap bank sebaiknya mampu menjaga dan meningkatkan Return On Asset (ROA) dan Net Interest Margin (NIM) yang dimiliki guna menjaga keberlangsungan bank karena ROA dan NIM digunakan sebagai indikator performance atau kinerja bank.

3. Penelitian ini hanya sebatas tiga faktor yakni faktor Risk Profil, Earning, dan Capital, karena focus penelitian ini hanya sebatas laporan keuangan bank yang dipublikasikan, sehingga diharapkan untuk penelitian selanjutnya dapat memperluas cakupan 
penelitian agar dapat melakukan penelitian terhadap keempat faktor yang terdapat dalam metode Risk Based Bank Rating (RBBR).

4. Dari penilaian kesehatan bank yang diteliti menggunakan RBBR bank yang memiliki kesehatan yang baik adalah Bank Central Asia, dan Bank Mandiri. Yang dinilai dari seluruh aspek RBBR dengan variabel LDR, ROA, NIM, dan CAR

\section{DAFTAR PUSTAKA}

Fadhila, Alizatul, Muhammad Saifi, dan Zahror Z.A. "Analisis Tingkat Kesehatan Bank Dengan Menggunakan Metode Risk-Based Bank Rating (RBBR) pada Bursa Efek Indonesia". Jurnal Administrasi Bisnis (Februari). Hal 2-5

Ghozali, Imam. 2005. Analisis Multivariate Dengan Program SPSS. Semarang: Badan Penerbit UNDIP.

Hakim A.F. Pengaruh Capital Adequacy Ratio, Loan Asset To Total Asset, Penyisihan Pengahapusan Aset Produktif, Financing To Deposit Ratio, dan Tingkat Suku Bunga Terhadap Profit Distribution Management Pada Bank Syariah. Universitas Pembangunan Nasional "Veteran".

Ismail. 2010. Manajemen Perbankan: Dari Teori Menuju Aplikasi, Jakarta : Prenada Media Group.

Krisnawati, Dira A. 2014. Analisis Faktor Penentu Profitabilitas Bank di Indonesia Dengan Metode RiskBased Bank Rating pada Bank-Bank Umum Go Publik di Indonesia. Skripsi. Semarang: Universitas Diponegoro.

Permatasari, Metalia, Nengah Sudjana, dan Muhammad Saifi. "Penggunaan
Metode Risk-Based Bank Rating Untuk Menganalisis Tingkat Kesehatan Bank pada Bursa Efek Indonesia". Jurnal Administrasi Bisnis (Mei). Hal 2-4. Septyaning, Merry Y. 2015. "Analisa Kinerja Bank Dengan Penerapan Metode Risk-Based Bank Rating pada Bursa Efek Indonesia" Jurnal Administrasi Bisnis (Januari), Hal 3-7.

Taswan. 2010. Manajemen Perbankan. Ed. 2, Yogyakarta : UPP STIM YKPN Yogyakarta.

Widyaningrum, Hening A, Suhadak, dan Topowijono. "Analisis Tingkat Kesehatan Bank Dengan Menggunakan Metode Risk-Based Bank Rating (RBBR) pada Bursa Efek Indonesia" Jurnal Administrasi Bisnis (April), Hal 4-5.

http://mncbank.co.id/id http://qnb.co.id/lang/en/ http://www.bankcapital.co.id/ http://www.bankmandiri.co.id/ http://www.bca.co.id/ http://www.bi.go.id/ http://www.bni.co.id/ http://www.boiindonesia.co.id/ http://www.bri.co.id/ http://www.bri.co.id/ http://www.jtrustbank.co.id/ http://www.victoriabank.co.id/ 